\title{
豚の新生児黄㾝症に関する研究
}

IV. 䀠血清中における赤血球に対する抗体の分布ならびに抗体産生要因について

\section{茂木一重・大石孝雄・阿部恒夫・姬野健太郎* ・細田達雄}

（農林省畜産試験場，*農林省九州農業試験場）

(1967. 11. 10 受付)

豚の新生児黄㾝症は目豚の血清中に何らかの原因で， 子豚の血球之強く反応寸る抗体が産生され，分娭直後の 新生児が哺乳により，初乳を介してこの抗体を腸管より

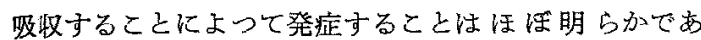
る。これまでに，新生児黄疸症の血清学的特異性 ${ }^{8}$ ，発 症子豚の血液性状江上る臨床所見 ${ }^{63}$ ，てして発症子豚の 病理組織学的所見》をすで報告した。抗体産生の原因 については,1954年 DoLl and BROWN ${ }^{11}$, 1955年 GoodWIN and SAISON ${ }^{2,5)}$ らは豚血液で作製された Crystal Violet Swine Fever Vaccine (CVV) の接種焂，母豚 血消中に血液型抗体を産生させる原因であること进報告 しているが，疑問の点が多い。

そこで本報は，我国における新生児黄㾝症の実態調査 の一環として，通常に飼育されている各年令の豚につい $\tau ，$ 血清中の抗体の分布状況を調查し，抗体産生の要因 について統計的分析陚子た。高なお方，我国では通常 年 2 回の CVVの接種方实施されているので，CVVの 接種が血液型抗体の産生汇どの程度関係しているか孝明 らかにし，年令の上昇，妊娠が抗体産生要因になる かでうかも检討を加元た。な GoodWIN and SAISON

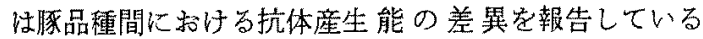
が，我国の主要品種間に打ける抗体の分布の差異を併せ て検討してみた。

\section{実験材料および方法}

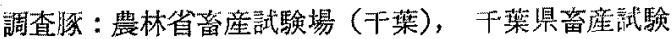
場，埼玉罧などで通常に飼育されている嘠 358 頭拉よび 農林省家畜衛生試駼場にけい養されているC V V 無接種 豚44頭艺調查した，調盗豚の品種の内訳は Yorkshire 種 167 頭, Landrace 䅤 65 頭, Berkshire 種 79 頭, $F_{1}(Y L)$

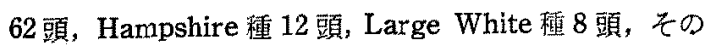
他 9 頭である. 年令は $0 \sim 7$ 年令におよえでいる。

採血方法拈上び血清の分離：成豚は耳静脈より，子豚 ( $0 \sim 3$ 力月令) 注胸骨前端右側総頚静脈より約 $5 \mathrm{~m} l$

日蓄会報，39，（4）：175-179
ずつ探血した。採取した血液は数时間室温放置後, また は $37^{\circ} \mathrm{C}, 30$ 分加温後, 血清を遠心分離した. 血清の非 働化法行な⿰なかつた。血清は $-20^{\circ} \mathrm{C}$ で保存した。

血清反応：血清中の抗体の検出法，遠心法 $(1,000 \mathrm{r}$.p. m., 1 分) 以上る直接凝集反応試験管法安用い, 血清の 稀䣋液火性生理的食塩水老用い, 反応は 2 倍稀积以上に ついて行なつた，凝集反応術式の細部についてはすでに 報告した通りである。非定型抗体検出のため Coombs Test も一部実施した。抗体検出のための反応血球とし ては，農林省畜産試験場飼省の特定の雌豚 3 頭の血球安 常に用い，来た干葉県畜産試験場，埼玉県下飼育の雄豚 血球をむ併世用いた：血球の採取に際してはへパりンを 㠜固防止剂として用い，生理的食塩水で 3 回洗㖓後 $2 \%$ 血球浮遊液としたものを反応用として用いた。

結果

（I）抗体の分布状況

i）全調查豚の抗体分布：全調査豚 402 頭について, 少なくとも 1 種の反店血球に対して，2 倍稀釈以上の抗 体を所有しているものの割合を調べると $62.2 \%$ \%であつ

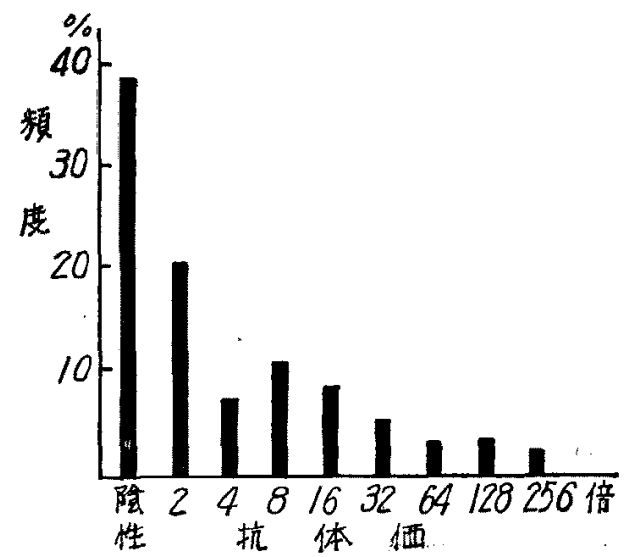

第1図 全調査溷に就ける抗体の分布 


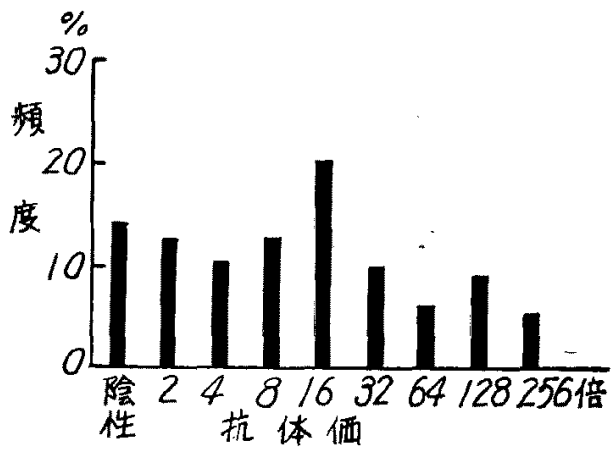

第 2 図 経産此豚化占讨る抗体の分布

た（四 1)。各飼育場所に扔ける抗体分布は，調查豚の 年命構成によつて影響を受けたが，顕著な差はみられな かつた，次に新生児黄疸症に関連して，調查豚中の経産 䅎だけについて抗体所有率を調べると，全経産豚 134 頭 中， 75 頭 $(85.2 \%)$ 名 2 倍稀积以上の抗体它所有してお り，その5ちでも40頭 $(29.9 \%)$ が32倍稀䣋以上の抗体 を所有していた（図2）。な䄧32倍稀釈以上という抗体 洒は，著者らが経㹲した新生児黄疸泟経歴母豚血清中の 抗体価である。

ii ）品種別の抗体分布：Yorkshire, Landrace, Berkshireの3 品種について，抗体分布の比較を行なつた。 この 3 品種证調查例数も多加た上に，我国の主要な品 種で京り，CVV接種回数の变異が各サンプル間にほと えど認好占れなかつたので，品種間の比較に適当之思わ れた。企の結果, Yorkshire 種は Landrace 種, Berk-

表 1 品種别の抗体分布

\begin{tabular}{|c|c|c|c|c|}
\hline 䅜 & 調查豚数 & 陰性豚数 & 陽性顼数 & $\begin{array}{l}\text { 平均抗体 } \\
\text { 俩 }\end{array}$ \\
\hline ヨークシャー & 167 & $\begin{array}{c}62 \\
(37.1 \%)\end{array}$ & $\begin{array}{c}105 \\
(62.9 \%)\end{array}$ & 11.48 \\
\hline ランドレース & 65 & $\begin{array}{c}12 \\
(18.5 \%)\end{array}$ & $\begin{array}{c}53 \\
(81.5 \%)\end{array}$ & 20.40 \\
\hline バークシャー & 80 & $\begin{array}{c}23 \\
(28.8 \%)\end{array}$ & $\begin{array}{c}57 \\
(71.2 \%)\end{array}$ & 28.25 \\
\hline
\end{tabular}

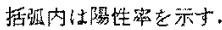

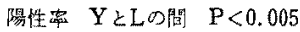
LをBの閏, $\mathrm{Y}$ と睡 $\quad \mathrm{P}>0.10$ shire 種に比べて，その陽性率および平均抗体価は低い 傾向が認的られた（表 1 )。

(II) $\mathrm{CVV}$ 接㮔之抗体価の関係

$\mathrm{CVV}$ 接種回数之平均抗体価乙の関係少調バると，接 種回数 8 回までは両者の間に $1 \%$ 水準で有意の相関関倸 が多られ，相関係数は 0.84 であった（図 3 ）。しかし， 9 回以上では抗体価注低下する傾向がみられた。な和， $\mathrm{CVV}$ 接種回数之年令, 分婏回数之はほ汪平行して上昇 するので，抗体洒の上䒜にCVV接種がぞの程度関与し ているかを，この图のみから明らがすることは困難で

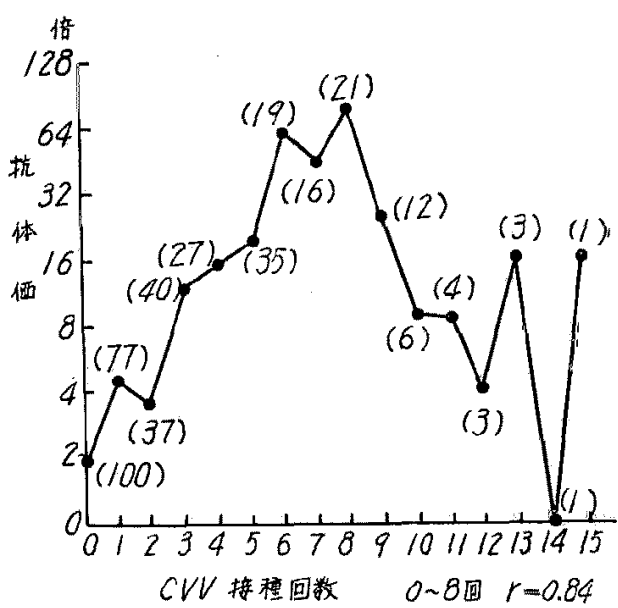

第 3 図 C V V接種回数之豚血清中の抗体佰之の関係

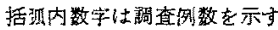

あつた。そこで，次の 5 点について，実験，分析を行な つた.

i ） C V V中の赤血球抗原の存在の有然：強い凝集反 店を起す反応系を用い，0.9\% 食湓水透析を行なつたC VVによる凝集阻止反応を実施した．その結果，CVV は明らか旗集反忘阻止を示し，C V V中に豚に対する 特異的な赤血球抗原が存在すること落考克られ，CVV 接種により血液型抗体が産生される可能性が考えられた (表 2)。なお，この点についてはさらに検討索加光当 定である。

ii ） CVV接種後の経過期間々抗体洒之の関係：CV $\mathrm{V}$ の最終の接種洔期から採血時期までの経過期閒と平均

表 2 透析 C V V Kよる豚血球凝集阻止反応

\begin{tabular}{|c|c|c|c|c|c|c|c|c|c|c|c|c|}
\hline \multirow{2}{*}{ 区 } & \multirow{2}{*}{ 応 } & \multirow{2}{*}{ 菒 } & \multicolumn{4}{|c|}{ 血 清 } & $の$ & \multicolumn{3}{|c|}{ 稀 橎 倍 率 (倍) } & \multirow[b]{2}{*}{512} & \multirow[b]{2}{*}{1024} \\
\hline & & & 2 & 4 & 8 & 16 & 32 & 64 & 128 & 256 & & \\
\hline \multicolumn{3}{|c|}{ 抗体稀积列 $+C V V+$ 血球 } & 3 & 3 & 2 & 1 & - & - & - & - & - & - \\
\hline \multicolumn{3}{|c|}{ 抗体稀秋列＋Saline＋血球 } & 4 & 4 & 4 & 4 & 4 & 3 & 3 & 2 & 1 & - \\
\hline
\end{tabular}


抗体価との関係を調べると，CVV接種後約 3 力月で抗 体洒分最高に達する傾向を示した（図4).

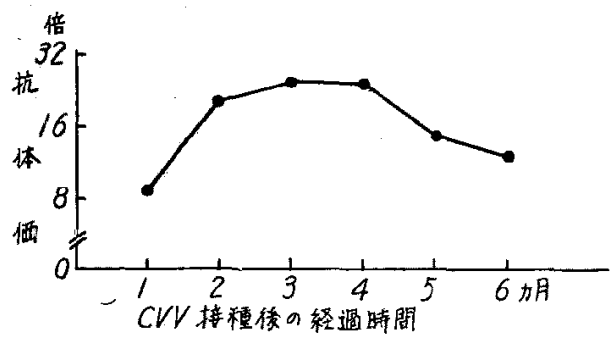

第 4 図 CV V接種後の経過期間乙抗体洒の関係

iii） 7 力月令における C V V接種豚之無接種豚の抗体 価の比較：約 7 カ月令で C V V 接種をまだ実施していな いCVV検定豚採血して，その血清中の抗体価と，通 常に䝭育されている7力月令豚（普通CVV1回接璉の 豚)の抗体亚を比較した。その結果，C V V無接種の豚 の平均抗体硒は，1回接種のものに比べて低い傾向が認 められたが，陽性率では䒜接種の豚の方が有意に高かつ i־ (就 3$)$. v）妊娠による影響：妊娠によつて母豚血清中に抗体

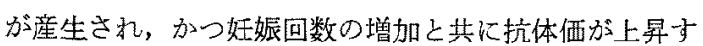
るか否かの分析を理想的に行なうには，CVV無接種で

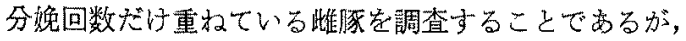
このような豚のサンプルを多く得ることが困難であつた ため，次のような分析方法を試みた．CV V接種 3 回の 此豚における経産 1 回) と末経産の比較, そして CVV 接種 3 回以上における踓豚と雄豚の比较家行なつた。

表 5 妊娠の抗体分布一の影算

\begin{tabular}{|c|c|c|c|c|}
\hline 分 & 調查豚类 & 陰性豚 & 圆性豚数 & $\begin{array}{l}\text { 平 均 } \\
\text { 抗体価 }\end{array}$ \\
\hline $\begin{array}{c}\text { 米絟崖豚 } \\
\text { (CVV3回接種) }\end{array}$ & 24 & $\begin{array}{c}5 \\
(20.8 \%)\end{array}$ & $\mid \begin{array}{cr}19 & \mathbf{a} \\
(79.2 \%)\end{array}$ & 14.40 \\
\hline $\begin{array}{c}\text { 経産 豚(1回) } \\
\text { (CV V } 3 \text { 回接種) }\end{array}$ & 14 & $\begin{array}{c}2 \\
(14.3 \%)\end{array}$ & $\begin{array}{r}12 \\
(85.7 \%)\end{array}$ & 11.00 \\
\hline $\begin{array}{l}\text { 経 應豚(数回) } \\
\text { (CV V 無接種) }\end{array}$ & 3 & $\begin{array}{c}1 \\
(33.3 \%)\end{array}$ & $\begin{array}{c}2 \\
(66.7 \%)\end{array}$ & 1.33 \\
\hline
\end{tabular}

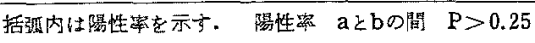

表 37 力月令に扔けるC V V接種豚と無接種豚の抗体価の比較

\begin{tabular}{|c|c|c|c|c|c|c|c|c|c|c|c|c|c|}
\hline \multirow{2}{*}{ 区 } & \multirow{2}{*}{\multicolumn{2}{|c|}{ 分 }} & \multirow{2}{*}{$\begin{array}{l}\text { 調查 } \\
\text { 豚数 }\end{array}$} & \multirow{2}{*}{$\begin{array}{l}\text { 陰性 } \\
\text { 豚数 }\end{array}$} & \multicolumn{2}{|c|}{ 抗 } & \multicolumn{2}{|c|}{ 体 } & \multicolumn{3}{|c|}{ 価（倍） } & \multirow{2}{*}{ 樶珄眽数 } & \multirow{2}{*}{ 平均抗体佂 } \\
\hline & & & & & 2 & 4 & 8 & 16 & 32 & 64 & 128 & & \\
\hline 無 & 接 種 & 豚 & 41 & 12 & 24 & 3 & 1 & 1 & 一 & - & - & $\begin{array}{c}29 \\
(70.7 \%)\end{array}$ & 2.05 \\
\hline 接 & ( 1 靣接種 $)$ & 膘 & 77 & 49 & 10 & 5 & 7 & 3 & 1 & 1 & 1 & $\begin{array}{c}28 \\
(36.4 \%)\end{array}$ & 4.80 \\
\hline
\end{tabular}

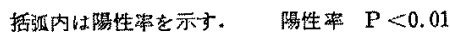

表 4 C V V無接種豚における年令による 抗体価の差異

\begin{tabular}{|c|c|c|c|c|c|c|c|c|}
\hline \multirow{2}{*}{ 月 令 } & \multirow{2}{*}{ 調査豚数 } & \multirow{2}{*}{ 㛬性 } & \multicolumn{4}{|c|}{ 抗体価（倍） } & & \multirow{2}{*}{ 平均 } \\
\hline & & & 2 & 4 & 8 & & & \\
\hline 2 力月令豚 & 56 & 43 & 7 & 1 & 4 & 1 & $(23.2 \%)$ & 1.18 \\
\hline ７力月令豚 & 41 & 12 & 24 & 3 & 1 & 1 & $(70.7 \%)$ & 2.05 \\
\hline
\end{tabular}

iv）CVV侮接種䀠における年令による抗体洒の差 暴：前述のCVV検定豚（約 7 力月令）と通常飼育のC $\mathrm{V} \mathrm{V}$ 無接種豚（約 2 力月令）乙の間に，C V V無接種で る年命によつて抗体分有に差買があるかどうが検討し

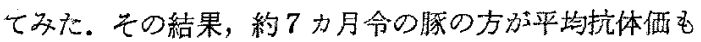
高く，かつ1\%水準で有意の满い陽性率を示した（表 4).

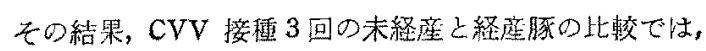
陽性率，平均抗体何乞もに，ほとえど差を示さなかつた が，参考程度に揭げた 3 頭の無接種の CVV 数回経産豚 で低い抗体洒示した（表 5 ）。次に CVV 接種 3 回以

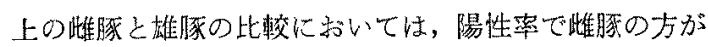
有意に高く，富た平均抗体唒も此豚の方が高かつた（表 $6)$.

$$
\text { 考察 }
$$

抗体定所有している瞅が予想外に多く，特に経座堆豚 中の30\%が32倍稀积以上の抗体艺所有していた点につい ては,これらの経産此隹腷の黄疸症経良は不明であるとし ても，大きな闍題となる可能性がある。勿諭，新生児黄 㾝症の発生には，交配雄豚の血液型乙の関係，その所有

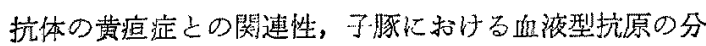
離など列関係しているので，今後これらの点と口関連性 を検討して行くつもりである。 
茂木·大石・阿部・姫野・細田

表 6 性による抗体分布への影響

\begin{tabular}{|c|c|c|c|c|c|c|c|c|c|c|c|c|}
\hline \multirow{2}{*}{ 性 } & \multirow{2}{*}{$\begin{array}{l}\text { 調查 } \\
\text { 豚数 }\end{array}$} & \multirow{2}{*}{$\begin{array}{l}\text { 陰性 } \\
\text { 豚数 }\end{array}$} & \multicolumn{3}{|c|}{ 抗 } & 体 & \multicolumn{2}{|c|}{ 価 } & （倍） & & \multirow{2}{*}{ 陽性豚数 } & \multirow{2}{*}{ 平均抗体価 } \\
\hline & & & 2 & 4 & 8 & 18 & 32 & 64 & 128 & 256 & & \\
\hline 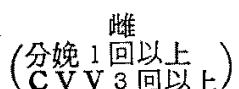 & 134 & 19 & 17 & 14 & 17 & 27 & 13 & 8 & 12 & 7 & $\begin{array}{l}115 \\
(85.8 \%)\end{array}$ & 36.67 \\
\hline $\begin{array}{c}\text { 雄 } \\
\text { (C V V } 3 \text { 回以上) }\end{array}$ & 31 & 11 & 6 & 2 & 6 & 1 & 2 & 2 & 0 & 1 & $\begin{array}{c}20 \\
(64.5 \%)\end{array}$ & 17.16 \\
\hline
\end{tabular}

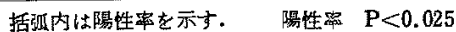

CVV 中には豚に特異的な血球抗原が存在しており， $\mathrm{CVV}$ 接喠回数と抗体価との高い相関, CVV 接璉 3 力 月後に抗体価が最高优達すること，および 7 カ月令豚の $\mathrm{CVV}$ 無接種と接種間で抗体洒に差異がみられたことな ぞから，GOoDWIN ら 2,5$)$ が報告しているように，CVV の接種が抗体産生の要因となることが明らかとなつた。

Berkshire 種, Landrace 種は Yorkshire 種に比べて 高い陽性率および平均抗体価定示したが，このこ之绎我 国の CVVが Yorkshire 種よりその全血字用いて作製 されていることに関係していると思われた。

$\mathrm{CVV}$ 接種回数 8 回以上で注，抗体価注逆に低下する 傾向が認められたが，その理由として高抗体価の豚では 繁殖成績少悪いために年令の上昇と共に淘汰されたとい うことがまず若えられ，そして調查例数の少ないことに よる偶然性また汪ある年令をピークとして抗体価が低下 することなども一因で恃いかと思われた。

2 力月令新よび 7 力月令の CVV 無接種豚でる，いか 济る自然抗体を有しており，また 7 力月令の豚の方が高 い踢性率，抗体価を示したことから，年令の上昇だけ炕 よっても若干抗体産生が促進されるのではない加と思わ れた。

妊娠に上つて抗体が産生されることが推察されたが， 結論を出すことができなかつたので，今後さらに検討を 加竞る予定である。

な打豚血清中の anti-A については，分婏直後の子豚 の血球中にはA抗原の発現がみられないので，本症に

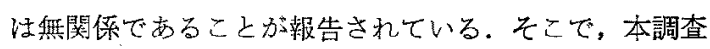
豚の所有抗体中に占める anti-A の制合について検討す ると $23.6 \%$ が anti-A 老有している可能性が推察され た。しかし，他の大部分は anti-A と無関係な抗体と思 われた。

以上の結果より，今後の研究の方向としては，抗体の

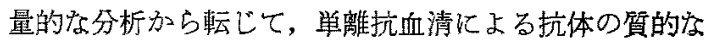
分析定試みて行くべきと考光られる。ささらに黄疸症関連 抗体が完全抗体か，あるいは人，馬に打けるよらに不完 全抗体であるか，もしくはその両者であるか，この点を
赤血球抗原の子豚における発育，新生児における腸管よ りの抗体の吸収のメカニズム，胎盤よりの抗体の吸収の 可否などの点から明らか炕する必要がある。なお， C V Vの赤血球抗原性については詳細に検討寸る予定であ る。

\section{要 約}

各年令の豚 402 頭につき，血清中の抗体の分布状況を 調ベた結果，次のような結論を得た。

1）全調查豚 402 頭中 $62.2 \%$ の のが 2 倍稀䐆以上の 抗体佃を有し，経産政豚においては 134 頭中 $30 \%$ が 32 倍稀勫以上の抗体索所有していた。

2）品種間に抗体所有の差異がみられ，Landrace 種, Benkshire 種は Yorkshire 種に比べて, 陽性率, 平均 抗体洒ともに高い傾向が認められた。

3）豚コレラワクチン（CVV）には豚に対する特異 的な赤血球抗原が認められ，その接㮔が抗体産生の要因 となることが推察された。

4）娃娠によつて抗体が産生される可能性がタられた が，結論を出すことはできなかつた。

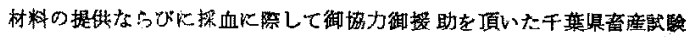

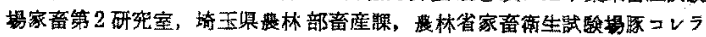
研兄室の諸氏に心から矿意を表する。

\section{文献}

1) Doli, E.R. and R.G.Brown (1953) Cornell Vet., 44: 86-93.

2) Goodwin, R.F.W. and R. SAison (1955) J.CompPath., $65: 79-92$.

3) Goodwin, R.F.W. and R. SAISON (1956)J. Comp. Path., $66: 163-178$.

4) Goodwin, R.F.W.and R.R.A. Coombs (1956) J. Comp. Path., 66 : 317-331.

5) Goobwin, R.F.W. and R. SAIson (1957) J.Comp. Path., $67:$ : 126-144.

6）姫野健太郎・長野鍊太郎・菻 淳 - 茂木一重・ 細田達雎（1967）日畜会報，38：167-174.

7）細田達雄・茂木一重・姫野健太郎 - 石田癸一・佐 藤昭夫（1968）日畜会報, 39:73-77.

8）茂木一重・細田達雄・姬野健太郎（1966）日畜会 報, $37: 296-300$. 


\title{
Résumé
}

\section{Studies on the hemolytic disease of newborn pigs}

IV. Distribution of blood group antibodies in the serum of pig, and analysis of the cause of antibody production

\author{
Kazushige Mogr*, Takao Oishi*, Tsuneo ABE*, Kentaro Himeno**, \\ and Tatsuo Hoson A* \\ (*National Institute of Animal Industry, Chiba-City, \\ **Kyushu Agricultural Experiment Station, Kumamoto Prefecture)
}

Hemolytic disease of the newborn is an acute hemolytic anemia acquierd in some species as a result of maternal antibodies against red cell antigen gaining access to the circulation of the offspring possessing these antigens, either in utero or immediately after birth.

However, the cause of the antibody production has not yet been fully understood. Previous papers dealt with serological, hematological, clinical and histological aspects of this disease.

This experiment was carried out to clarify antibody titer in the sera of pigs of different breeds and age with special reference to the distribution pattern in the field, and the cause of the antibody production was discussed.

The results were as follows:

1. Four hundred and two heads of different age of Landrace, Berkshire and Yorkshire Breed were used. Thirty per cent of 134 sows possessed high titer $(1: 32$ or higher) of the antibodies.

2. There were some difference in antibody production among breeds. In Landrace and Berkshire, the percentage of possitive reaction and the average titer of the antibodies were higher than those in Yorkshire.

3. A correlation was detected between the times of Crystal Violet Swine Fever Vaccine (CVV) injection and the antibody titer in the sera of pigs. Since the blood group antigenicity was still persistent in CVV, the possibility is persumable of iso-immunization of the sows by CVV injection.

4. Pregnancy may play some role on the production of antibody, which, however, is still to be investigated. 